\title{
PSYCHOSEMANTIC ANALYSIS OF THE CONCEPT OF MANAGER'S COMPETENCE
}

\author{
Liudmyla Malimon \\ malimon.ludmila@eenu.edu.ua \\ Alla Pashkina \\ pashkina.alla@eenu.edu.ua
}

Lesya Ukrainka Eastern European National University, Ukraine

Received November 26, 2019; Revised December 16, 2019; Accepted December 27, 2019

\begin{abstract}
The article deals with the psychosemantic reconstruction of the concept of manager's competence. The study is based on free word association test (WAT) held with the managers of public administration $(n=38)$ from Volyn Oblast (Ukraine) and master candidates of the public administration program $(n=38)$ who studied at Eastern European National University in Lutsk (Ukraine). Nuclear zones, single frequency responses, and associative field structure of the investigated concept in the two samples were analyzed. The most frequent nuclear associations confirmed the lexicographic meaning of the concept "competence" and revealed that the leader's expertise is closely related to their professional knowledge and skills. Next, factor analysis of data obtained from the Semantic Differential (SD) test established common and distinctive features of the semantic field structure of the concept of manager's competence. The research results showed that the managers from the sample emphasized the importance of experience and effectiveness, the development of their professionally relevant job skills and ability to influence their subordinates. By contrast, master candidates, along with experience and job skills, indicated a set of characteristics that demonstrate the need for a general intellectual level of the managers, their moral and ethical personality traits, and their ability to maintain effective interpersonal interaction.

Keywords: psychosemantic analysis, manager's competence, concept, public administration, free word association test, semantic differential.
\end{abstract}

\section{Малімон Людмила, Пашкіна Алла. Психосемантичний аналіз концепту «управлінська компетентність».}

Анотація. Статтю присвячено психосемантичній реконструкції концепту «управлінська компетентність». Дослідження здійснено на основі методу вільного асоціативного експерименту, проведеного 338 менеджерами державної служби Волинської області (Україна), а також 38 здобувачами ступеня магістра освітньо-професійної програми «державна служба». Проаналізовано ядерні зони, реакції з одиничною частотністю та структуру асоціативних полів досліджуваного концепту у двох вибірках. Виокремлено найчастотніші ядерні асоціації, які підтвердили лексикографічне значення слова «компетентний» і пов'язують компетентність керівника з його професійними знаннями й уміннями. Зіставлено результати факторного аналізу даних семантичного диференціалу. Підсумком є з'ясування спільних і відмінних ознак у структуруванні семантичних полів концепту «управлінська компетентність»: керівники державної служби підкреслюють важливість досвіду й результативності діяльності керівника, розвитку його професійно важливих управлінських якостей і здатності впливати на інших. Натомість, студентимагістри, поряд із досвідом та результативністю праці, виокремлюють групи характеристик, що засвідчують потребу загального інтелектуального рівня керівника, розвитку його

C Malimon, Liudmyla; Pashkina, Alla, 2019. This is an Open Access article distributed under the terms and conditions of the Creative Commons Attribution 4.0 International Licence (http://creativecommons.org/ licenses/by/4.0).

East European Journal of Psycholinguistics, 6(2), 58-67. https://doi.org/10.5281/zenodo.3637737 
морально-етичних особистісних рис та вміння налагоджувати ефективну міжособистісну взаємодію.

Ключові слова: психосемантичний аналіз, управлінська компетентність, конщепт, державна служба, вільний асочіативний експеримент, семантичний диференціал.

\section{Introduction}

The reform of public administration institute in our country presupposes implementation of the EU standards, in particular, the competence-based approach, in the assessment of performance, system of education and advanced professional training of civil servants. Due to this in recent years considerable research has been devoted to the issues of raising the performance of civil service personnel management, the necessity of existing civil servants professional competence profiles development and improvement, their compatibility with the realia of professional activity; definition of clusters of competences necessary to fulfill professional duties of a certain position, including the ones essential for senior government officials of senior and middle management (Zhminka, 2013; Kukulia, 2012; Lyndiuk, 2015).

At the same time it is worth mentioning that recent years have seen considerable changes in public inquiry about the assessment of state institutions not only from the point of view of their performance in providing administrative service and meeting the demands of society to the maximum extent, but also referring to the attitude to civil servants as to individuals who present worldview and moral value orientations in the development of society and the country in general. That is why the competence-based approach focuses on formation and development of not only professional, but also the so-called key (social and personal) competences of a civil servant (Bolotina, 2017).

Well-formedness of the latter ones depends greatly on civil servants' reportable and unconscious attitudes to perceiving their own competence and understanding the necessity to develop those features and characteristics, which constitute its basis. Definition of such attitudes as well as definition of the essence and details of the concept of "management competence" require the reconstruction of the manager personal meaning system, through which they perceive themselves as competent or incompetent. It has been possible only due to application of the set of methods used in psycho-semantics, a modern branch of investigation which studies the genesis, structure and functioning of the personal meaning system (Drobot, 2014).

\section{Methods}

The purpose of our research is the psycho-semantic reconstruction of the concept of "manager's competence" semantic field, as well as contrasting and comparing its semantic scope in the Government Agencies' Executives (managers) and Master's students doing a degree in Public Administration.

The survey sample comprises managers of state institutions in Volyn Oblast $(\mathrm{n}=38,47 \%$ males and $53 \%$ females, with 3-16 years of seniority in top management) and Eastern European National University master's students doing a 
degree in Public Administration ( $\mathrm{n}=38,34 \%$ males, $66 \%$ females, with no work experience in the filed). The respondents were informed about the anonymous character of the survey and the possibility to resign on any stage.

The word association test (WAT) is an important tool of semantic research (Lat. associato - combination, experimentum - experience), which is widely used to study the peculiarities of comprehension and recognition of the concepts used by the speakers and it provides "live" data to build associative fields of certain concepts, to reconstruct fragments of linguistic and conceptual worldview. We have used the modified version of the "Sentence Completion" method which refers to projective diagnostics and is a variation of the Word Associations technique. It is considered that the associations received present both reportable and unconscious attitudes of a person to the perception of certain concepts or phenomena (Petrenko, 2005). The associative method represents cognitive structures behind linguistic meanings, individual peculiarities of the examined and their personal senses (Drobot, 2014; Lozova, 2007).

The method of semantic differential, which is treated as a combination of the method of controlled associations and scaling procedures, has become an experimental method of personal meaning system reconstruction and individual and group semantic spaces of the concept of "management competence" construction (Drobot, 2014; Petrenko, 2005; Lozova, 2007).

The professional concept offered to the examined in the free WAT was the concept of "manager's competence", namely, it was required to complete the sentence "A competent manager is a ... manager" with a set of associations (the number of associations was unlimited) within a specific time period. The WAT was carried out in written form and it complicated spontaneous response but contributed to the respondents' professional experience actualization. As a result, 350 wordsassociations have been received, which outlined the semantic field of responses on the word-stimulus. Processing of the results has been carried out using the method of ranking the words given by the examined according to the frequency of the representation: association responses given more than three times have been considered to be an association norm; primary (nuclear) and secondary (peripheral) associations have been analysed.

The next stage of the research is construction of the semantic differential method on the basis of the most frequent associations received in the word association test.

\section{Results and Discussion}

The lexicographic meaning of the word "competent" (Lat. competens (competentis) - appropriate, able) is given as "1) the one who has enough knowledge in any branch; the one who is knowledgeable about something; smart ( $a$ competent person) // based on knowledge; qualified (competent help, competent opinion); 2) the one who has certain powers; fully legitimate, sovereign (competent meeting)" (DUL, 1973, p. 250). The word "competent" has the following synonyms: (expert) knowledgeable, smart; (craftsman) qualified; (government official) fully 
legitimate, plenipotent, sovereign (Karavansky, 2000, p. 170). The meanings of the word "competent" in English: "competent (adj.): having necessary ability, knowledge, or skills to do something successfully; (of a person) efficient and capable; acceptable and satisfactory, though not outstanding; (of a court or other body) accepted as having the legal authority to deal with a particular matter" (Stevenson, 2010, p. 355). So, in the lexicography the word "competent" is primarily connected to knowledge, skills and abilities of people, which make them knowledgeable, smart, qualified, capable in a certain field. We have compared the dictionary definition which mainly confirms the constant meaning of the word, with the associative ones, which have been received as the result of the free WAT and represent meanings, connected with this word in the consciousness of the respondents.

As in our research the term "competent" characterizes a competent manager and aims at defining personal-semantic correlates of the concept of "management competence", we have analysed associative fields of this concept received in two sample groups: managers of state institutions and Master's students. The managers' of state institutions associative field contains 166 responses, including 25 nuclear associations, 16 responses with unitary frequency. In the master's students' associative field we have defined much more responses (184), but fewer nuclear associations (21) and, comparing to managers, more peripheral responses (22), which represent individual attitude of the respondents. The analysis of the received associations has made it possible to combine them in groups and single out generalized blocks of the competent manager characteristics. We have compared the associative fields nuclear zones and structures in the two samples:

Table 1

Comparison of the associative fields nuclei of the "manager's competence" stimulus in the two samples

\begin{tabular}{lll}
\hline $\begin{array}{c}\text { Generalized } \\
\text { blocks of the } \\
\text { competent } \\
\text { manager } \\
\text { characteristics }\end{array}$ & $\begin{array}{c}\text { The associative field } \\
\text { nucleus of the "manager's } \\
\text { competence" stimulus in } \\
\text { the group of managers }\end{array}$ & $\begin{array}{l}\text { The associative field } \\
\text { nucleus of the "manager } \\
\text { competence" stimulus in } \\
\text { the group of master's } \\
\text { students }\end{array}$ \\
\hline $\begin{array}{l}\text { Professional } \\
\text { knowledge and } \\
\text { skills }\end{array}$ & $\begin{array}{l}\text { qualified (14), literate (10), } \\
\text { cognizant (8), } \\
\text { professional (4), } \\
\text { knowledgeable (3) }\end{array}$ & $\begin{array}{l}\text { qualified (15), } \\
\text { literate (12), } \\
\text { innovative (12) }\end{array}$ \\
$\begin{array}{l}\text { Experience and } \\
\text { productivity }\end{array}$ & $\begin{array}{l}\text { experienced (12), high- } \\
\text { performance (7), effective }\end{array}$ & $\begin{array}{l}\text { high-performance (12), } \\
\text { effective (7), } \\
\text { experienced (3) }\end{array}$ \\
$\begin{array}{l}\text { Overall } \\
\text { intellectual level } \\
\text { intelligent (3), educated (3) }\end{array}$ & $\begin{array}{l}\text { erudite (10), } \\
\text { intelligent (7) }\end{array}$ \\
$\begin{array}{l}\text { Social and } \\
\text { personal self- } \\
\text { realisation }\end{array}$ & $\begin{array}{l}\text { mature (8), independent (3), } \\
\text { successful (12), } \\
\text { realised (3), self-sufficient }\end{array}$ & independent (3), \\
\hline
\end{tabular}




\begin{tabular}{|c|c|c|}
\hline $\begin{array}{l}\text { Ability to } \\
\text { influence others }\end{array}$ & $\begin{array}{l}\text { strict (exacting) (9), tough } \\
\text { (9), influential (5), bossy }\end{array}$ & $\begin{array}{l}\text { authoritative (11) } \\
\text { strict (exacting) (4) }\end{array}$ \\
\hline $\begin{array}{l}\text { Professionally } \\
\text { significant } \\
\text { managerial } \\
\text { qualities }\end{array}$ & $\begin{array}{l}(3), \\
\text { responsible (7), a person of } \\
\text { principle ( } 7)\end{array}$ & responsible (5) \\
\hline $\begin{array}{l}\text { Moral-ethical } \\
\text { personal qualities }\end{array}$ & $\begin{array}{l}\text { tactful }(7), \\
\text { cultured (3) }\end{array}$ & $\begin{array}{l}\text { well-bred (9), } \\
\text { intellectual(5), } \\
\text { honest (5), sincere (4), } \\
\text { friendly (3) }\end{array}$ \\
\hline $\begin{array}{l}\text { Performance of } \\
\text { interpersonal } \\
\text { cooperation }\end{array}$ & sociable (8), empathic (4) & $\begin{array}{l}\text { empathic (12), tolerant } \\
(8) \text {, sociable (3) }\end{array}$ \\
\hline
\end{tabular}

So, the most frequent nuclear associations are as follows: in the group of managers - qualified (14), literate (10), cognizant (6), professional (6); in the group of master's students - qualified (19), literate (12), innovative (12). They define the major qualities which confirm the lexicographic meaning of the word "competent" and connect competence of a manager to their professional knowledge and skills. These qualities are revealed much brighter within the whole associative field taking into account all the answers, including exceptional ones. In addition, among the most numerous associations in the group of managers there are the responses that characterize a competent manager from the point of view of experience and performance of management activity, the ability to influence others and the professionally significant managerial qualities. In the group of master's students there are also more associations which refer to experience and productivity of the manager work, but the group of features has been singled out, which emphasize the importance of the overall intellectual level of a manager, in particular, erudition, their moral-ethical personal qualities development and the skill to establish effective interpersonal cooperation.

Unitary responses are also rather interesting as the sample groups have gone beyond the limits of the task given. They have used syntactical structures (wordcombinations, sentences), but not only adjectives, as associations characterizing a competent manager in a descriptive manner. In particular, in the group of managers we have come across the following responses: manager-mentor; high-level professional; passionate about their work; put interests of the company above personal ones; is an example to follow; people put trust in them; is able to delegate. The peripheral responses in the group of managers are as follows: competitive, determined, fair, mature, practical, organized.

The master's students characterize a competent manager as the one who: believes in people; trusts people; manager-leader, motivator; treat themselves as members of the team, not bosses; team-player; provides an opportunity for selfrealisation to their employees. The peripheral associations in this group are as 
follows: humane, sympathetic, well-read, fair, understanding, kind, hard-working, fun, effective, positive, ethical.

So, unitary responses confirm the general tendency in the two sample groups treating manager competence as the synergy of their knowledge and experience, and also reveal some differences in how the managers themselves understand manager competence (an ability to influence people, be mentors, examples to follow, be trusted) and how the Master's student understand it (treating it as depending on moral-ethical qualities of a manager (leader, motivator, a team member) and qualities which provide positive social-psychological atmosphere in the company).

The second method used in the research is the method of Semantic Differential to build subjective semantic spaces of the concept of "management competence" in the two sample groups. As the most frequent associations express the main semantic value and reflect the qualities which, on the whole, represent a certain concept in the consciousness of respondents, they have constituted the basis of constructing the procedure and have created 20 bipolar gradual scales the poles of which have been defined with verbal antonymic pairs of such associations as: qualified, experienced, wise, tactful, innovative, literate, intelligent, erudite, high-performance, tolerant, well-bred, mature, successful, tough, authoritative, strict (exacting), sociable, empathic, responsible, a person of principle.

The results processing has been conducted with the help of factor analysis using the Principle Component method. To define the number of factors we have used the Kaiser Criterion (the number of factors corresponds to the number of components with the value bigger than 1). The validity of Factor analysis method application to the sample groups has been also checked with the Kaiser-MeyerOlkin criterion (the value of correlation between a factor and variables included in its structure, which is less than .6 has not been taken into account) and with the Bartlett spherical criterion $(\mathrm{p} \leq .001)$. In such a way the dimension of semantic concepts has been decreased and the content of the concept of "manager's competence" has been specificated.

The semantic space factor structure of the concept of "manager's competence" in the sample of managers has been formed by eight factors with the factor loading from $9.48 \%$ (factor one) to $8.28 \%$ (factor eight), that describe $70.37 \%$ of data array dispersion. Factor one, bipolar, is presented with the following scales with factor loading: qualified (.87), high-performance (.65), intelligent .61), a person of principle (.49). Factors two and three, unipolar, comprise the scales literate (.79), responsible (.74) and experienced (.67), wise (.61) respectively. Factor four is represented with the scales tough (.86) and successful (-.65); factor five - strict (exacting) (.71), mature (.70), authoritative (.55); factor six - erudite (-.80), wellbred (.67), innovative (.52); factor seven - tactful (.87), tolerant (.65); factor eight sociable (.80), empathic (.67). So, according to the results of the factor analysis three scales with the opposite poles have been singled out (intelligent, successful, erudite), which define the qualities that are certain to be less important for the managers in their attitude to manager competence. Assigning the names to the factors due to their semantic elements with the most important value, in the 
semantic space factor structure of the concept of "manager's competence" there may be singled out the sub-structures of qualification, literacy, experience, toughness, strictness, tactfulness, sociability and with an opposite mark - erudition, that reflect managers' opinion of manager competence.

In the student sample the semantic space factor structure of the concept of "manager's competence" is also presented by the eight factors which describe $70.21 \%$ of data array dispersion, but with a little more differentiated factor loadings: from $11.20 \%$ (factor one) to $6.55 \%$ (factor eight). In particular, factor one is created with the semantics of the three scales: high-performance (.80), a person of principle (-.74), intelligent (.57); factor two is presented by the two scales: authoritative (.74), wise (.73), strict (exacting) (.55); factor three - erudite (0.74), tactful (-.66), mature (.59), tough (-.56); factor four - experienced (-.77), responsible (.76); factor five - tolerant (.84), well-bred (.71); factor six is created by one scale - innovative (.84); factor seven - empathic (.81), sociable (.66), successful (.50); factor eight - literate (.91), qualified (.65). In the factor structure of students' understanding of manager competence there have been singled the scales with opposite poles: a person of principle, tactful, tough, experienced, so, their value in the semantics of the concept under consideration may be considered a little less important. At the same time, the semantic space factor structure of the concept under consideration is presented by the sub-structures of performance, authority, erudition, experience (with the "-" mark), tolerance, innovativeness, empathy, literacy, that represents students' attitude to manager's competence.

Semantic field factor structures are illustrated in the coordinate plane with $\mathrm{Y}$-axis and $\mathrm{X}$-axis, that represent percipiency and measure of perception of the concept of "manager's competence" by the two samples (Figures 1-2).

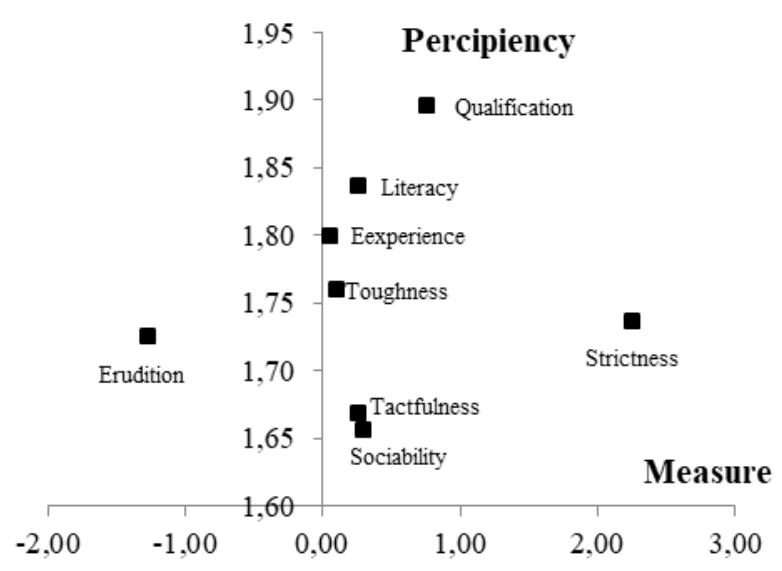

Figure 1. Semantic space of the concept of "manager's competence" perceived by managers

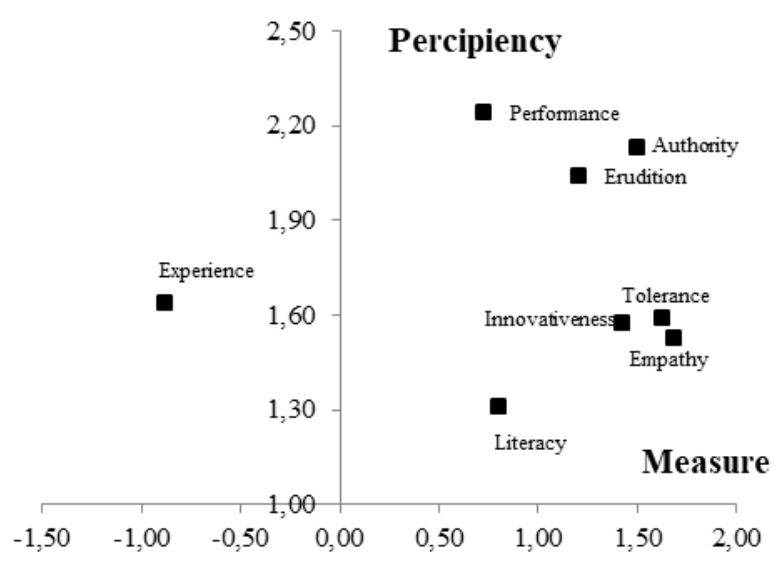

Figure 2. Semantic space of the concept of "manager's competence" perceived by students

It is obvious that absolute majority of the defined factors are located in the upper right quadrant of the coordinate plane, which is defined by the vectors of percipiency and measure, and it confirms that the respondents realise the importance 
of these factors in management competence understanding. The exception is the factor of erudition in the group of managers, which is referred to the negative pole and it may confirm that management competence may be treated as the one which does not require any wide erudition, but much deeper (narrow, branch-related, subject-related) knowledge in a certain field. In the group of students such factor is experience, denial (or disregard) of which may be explained taking into account the age of respondents and their desire to see themselves (or their peers) as competent managers despite the lack of experience.

At the same time, according to the vector of percipiency, in the group of managers the highest values have been defined in the qualities of qualification, literacy, experience, toughness, and in the group of students - in the qualities of performance, authority, erudition. These categories are characterized with the highest level of psychic stimulation. It may confirm their high importance in the system of respondents' attitudes to management competence. Such qualities as tactfulness and sociability (a group of managers) and literacy (a group of students) have lower values according to the vector of percipiency.

The distribution of the results according to the vector of measure is also interesting: in the group of managers all the characteristics (but for strictness) are shifted to the middle of the scale, which indicates neutral unbiased attitude of the respondents to them; in the group of students such qualities as authority, erudition, tolerance, innovativeness, empathy are close to the pole of scale, which may confirm that they are more appealing, desirable and emotionally rich for the respondents in their understanding of management competence.

\section{Conclusions}

The analysis of the data received as the results of word association test and semantic differential of the concept of "manager's competence" reveals that the most important components of its semantic space structure in both sample groups are the sub-structures of professional knowledge, skills and performance of a manager. At the same time, some differences have been defined in understanding of importance of experience, professionally significant and personal (moral-ethical) qualities and those features of a manager, which influence effectiveness of professional and interpersonal cooperation in the company.

\section{References}

Болотіна С. В. Компетентнісний підхід в державному управлінні: становлення та еволюція // Економічний вісник Донбасу. 2017. № 3(49). С. 138-145.

Bolotina, Ie. V. (2017). Kompetentnisnyi pidkhid v derzhavnomu upravlinni: stanovlennia ta evoliutsiia. [Competence-Based Approach in State Administration: Establishment and Evolution.] Ekonomichnyi Visnyk Donbasu, № 3(49), 138-145.

Дробот О. В. Психосемантика управлінської свідомості керівника: монографія. Донецьк: Східний видавничий дім, 2014.

Drobot, O. V. (2014). Psykhosemantyka upravlins'koii svidomosti kerivnyka [Psychosemantics of the Managerial Consciousness of the Leader]. Donetsk: Skhidnyi Vydavnychyi Dim. 
Жмінка С. П. Зарубіжний досвід впровадження компетентнісного підходу в державне управління // Ефективність державного управління: зб. наук. праць. 2013. Вип. 37. C. 451-458.

Zhminka, S. P. (2013). Zarubizhnyi dosvid vprovadzhennia kompetentnisnoho pidhodu v derzhavne upravlinnia [Foreign experience of competence-based approach implementation into state administration]. Efectyvnist' Derzhavnoho Upravlinnia, 37, 451-458.

Кукуля А. Принципи професіоналізму державних службовців та профілі професійної компетентності посад державної служби // Вісн. держ. служби Украӥни. 2012. № 3. C. $11-17$.

Kukulia, A. (2012). Pryntsypy profesionalizmu derzhavnykh sluzhbovtsiv ta profili profesiinoii kompetentnosti posad derzhavnoii sluzhby [principles of civil servants professionalism and civil service positions professional competence profiles]. Visnyk Derzhavnoyi Sluzhby Ukrainy, 3, 11-17.

Линдюк О. Профілі професійної компетентності державних службовців як складова модернізації державної служби // Державне управління та місиеве самоврядування. 2015. Вип. 4(27). С. 187-199.

Lyndiuk, O. (2015). Profili profesiinoii kompetentnosti derzhavnykh sluzhbovtsiv iak skladova modernisatsii derzhavnoii sluzhby [Civil servants professional competence profiles as a component of civil service modernization]. Derzhavne Upravlinnia ta Mistseve Samovriaduvannia, 4(27), 187-199.

Лозова О. М. Психосемантика етнічної свідомості. К: Освіта України, 2007.

Lozova, O. M. (2007). Psykhosemantyka Etnichnoii Svidomosti [Psychosemantics of Ethnic Consciousness]. Kyiv.

Петренко В. Ф. Основы психосемантики. СПб.: Питер. 2005.

Petrenko, V. (2005). Osnovy Psikhosemantiki [Foundations of Psychosemantics]. S.-Petrsburg: Piter.

\section{Dictionaries}

Караванський С. Практичний словник синонімів української мови. Київ, 2000.

Словник української мови: в 11 томах. Академічний тлумачний словник (1970-1980). Т. 4. 1973. C. 250.

Stevenson, A. (Ed.). (2010). Oxford Dictionary of English. Oxford University Press, USA.

\section{References (translated and transliterated)}

Bolotina, Ie. V. (2017). Kompetentnisnyi pidkhid v derzhavnomu upravlinni: stanovlennia ta evoliutsiia. [Competence-Based Approach in State Administration: Establishment and Evolution.] Ekonomichnyi Visnyk Donbasu, № 3(49), 138-145.

Drobot, O. V. (2014). Psykhosemantyka upravlins'koii svidomosti kerivnyka [Psychosemantics of the Managerial Consciousness of the Leader]. Donetsk: Skhidnyi Vydavnychyi Dim.

Zhminka, S. P. (2013). Zarubizhnyi dosvid vprovadzhennia kompetentnisnoho pidhodu v derzhavne upravlinnia [Foreign experience of competence-based approach implementation into state administration]. Efectyvnist' Derzhavnoho Upravlinnia, 37, 451-458.

Kukulia, A. (2012). Pryntsypy profesionalizmu derzhavnykh sluzhbovtsiv ta profili profesiinoii kompetentnosti posad derzhavnoii sluzhby [principles of civil servants professionalism and civil service positions professional competence profiles]. Visnyk Derzhavnoyi Sluzhby Ukrainy, 3, 11-17.

Lyndiuk, O. (2015). Profili profesiinoii kompetentnosti derzhavnykh sluzhbovtsiv iak skladova modernisatsii derzhavnoii sluzhby [Civil servants professional competence profiles as a component of civil service modernization]. Derzhavne Upravlinnia ta Mistseve Samovriaduvannia, 4(27), 187-199. 
Lozova, O. M. (2007). Psykhosemantyka Etnichnoii Svidomosti [Psychosemantics of Ethnic Consciousness]. Kyiv: Osvita Ukraïny.

Petrenko, V. (2005). Osnovy Psikhosemantiki [Foundations of Psychosemantics]. S.-Petersburg: Piter.

\section{Dictionaries (translated and transliterated)}

Karavansky, S. (2000). Praktychnyi Slovnyk Synonimiv Ukrains'koii Movy [The Practical Dictionary of the Ukrainian Language Synonyms]. Kyiv.

Slovnyk ukrains 'koii movy: v 11 tomakh. Akademichnyi tlumachnyi slovnyk. (1970-1980) (1973).. [Dictionary of the Ukrainian Language: in 11 Volumes. Academic Dictionary. 1970-1980], 4, 250.

Stevenson, A. (Ed.). (2010). Oxford Dictionary of English. Oxford University Press, USA. 